\title{
The Rehabilitation Role of Punishment in Prisons in Italy. Theoretical Development and Sociological Considerations
}

\author{
Maurizio Esposito \\ Department of Human, Social and Health Sciences, University of Cassino and Lazio Meridionale, \\ Cassino, Italy \\ Email: m.esposito@unicas.it
}

Received 9 January 2014; revised 21 February 2014; accepted 12 March 2014

Copyright (C 2014 by author and Scientific Research Publishing Inc.

This work is licensed under the Creative Commons Attribution International License (CC BY). http://creativecommons.org/licenses/by/4.0/

\begin{abstract}
This article deals with punishment and prisons, in particular, the rehabilitative role of punishment in Italian prisons. This role is herewith specified: On the one hand, by sociological considerations on punishment and prisons, based on the studies of Clemmer and Goffman; on the other hand, by international rules and the Italian legislation, dating back to the Reform of the Penitentiary Code 1975 and lastly, from a critical point of view. Generally speaking, the term rehabilitative model in this context means to restore solidarity with the socially recognized values, reconstructing the broken citizenship bond.
\end{abstract}

\section{Keywords}

Prison; Rehabilitation; Society; Sociology; European Rules

\section{Introduction. The Functions of Punishment}

This article begins with an introduction on the function and role of punishment. Generally, three main theories on the role of punishment are outlined: the idea of retribution, general prevention and special prevention.

These theories can be divided into two broad groups, which can be described by using a formula dating back to Seneca's De Ira which says: nemo prudens punit, quia peccatum est, sed ne peccetur (the wiseman does not punish because the action committed is a sin, but so that the sin is not committed again in the future). Following this Latin formula, on one hand, there are doctrines justifying punishment according to "quia peccatum est", taking into account only the harm or criminal act committed, and therefore look to the past; on the other hand, there are doctrines that justify the punishment according to "ne peccetur", considering the good, the aim or 
objective resulting from the punishment, and thus look to the future. The great distinction refers to the possibility that there is a purpose, a social benefit, a quid pluris instead of the punitive component only. According to the first group, punishment finds its reason in itself, whereas, for the second group, it is a means to obtain an extrinsic scope, and precisely, benefits for society.

The distinction between absolute and relative doctrines derives from the German doctrine, while the AngloSaxon coins the distinction between the retributive and utilitarian theory. In general, the two distinctions are corresponding: in fact, the absolute theory tries to find only the retributive function in punishment intended as the extent of punishment equivalent to the harm done, while, where punishment has a relative purpose, this corresponds to social utility, which will generally be prevention (Vianello, 2012).

The principle on which the idea of retribution is based is that it is fair, legitimate and right to reward evil with evil: punishment is proportional to the harm done. Punishment is seen as a purpose in itself, and this is the characteristic of its absoluteness: its justification is not the purpose it should reach, but the realization of the idea of justice.

The absolute or retributive doctrines are divided according to the moral or legal value assigned to the retributive punishment. For the moral retribution, punishment is a profound and undeniable ethical requirement of human consciousness: considering crime a violation of ethical order, moral conscience requires its punishment. For legal retribution, on the contrary, punishment finds its basis, not externally but within the legal system.

The relative or utilitarian doctrines are differentiated between doctrines of special prevention, for which punishment is a means to eliminate or reduce the danger that the subject can commit the crime again in the future; and doctrines of general prevention for which the sanctions have the function of "preventing" crimes by intimidation. Consisting of a suffering, punishment is meant to deter individuals from committing criminal acts: prison must show the offenders their mistakes in order to discourage recurrence.

The third theory, finally, gives punishment the rehabilitative role in order to re-enter the offender into society in order to favour civil progress. To prevent the offender's relapse, it is necessary to correct, improve, educate, but also help him regain self-confidence and self-esteem. Prison is seen as a place to convey a new set of values to prisoners (a new Weltanschauung).

Prison can be considered a total institution (infra), which has the purpose to penalize individuals who have committed a crime, by detention in a closed place in which the prisoner's freedom of movement is severely limited. Prison as a place of punishment is seen as a natural fact: the person who commits a crime must serve his sentence by passing a certain period of his life locked up in an institutional space defined "prison". However, as a means of punishment execution, this is a relatively recent creation (Ibidem).

In the Middle Ages prison was only a place where the accused person was kept pending trial. In a precapitalist world prison as punishment does not exist; this statement is historically verifiable with the fact that it is not the prison as an institution which is ignored but the internment punishment as a deprivation of liberty. The criminal systems of ancient régime knew many different punitive modes. Most of these methods inflicted physical body pain (lashing, amputation, various types of torture used mostly in the preliminary inquiry stage), to the death penalty, which, however, was not performed, as nowadays, without causing pain and secretly, but in public and through the "art" of causing extreme pain to the condemned. Other punitive methods were, instead, relatively less painful: fines as punishment, exile or banishment, "galley jail" punishment consisting of being doomed to become rowers on vessels, punishments exposing the offender to public ridicule (for example pillory or public admission of guilt by the offender before the courts). From the second half of the seventeenth century such punishments were gradually abandoned and replaced with prison punishment which, within a few decades, becomes the primary mode of punishment. Between the end of the seventeenth century and the early eighteenth century, under the Enlightenment influence, the first steps towards humanization of punishment are made and the role of detention instead of corporal punishment emerges in punishment executions.

\section{Sociological Considerations of Prisons and Prisoners}

What happens in modern prisons? How is it experienced by the prisoner? What are the main management problems?

\subsection{Prison as a Total Institution}

One of the main aspects characterizing a prisoner's life compared to a free citizen's is the forced separation from 
his native place and affections: loss of freedom means an involuntary renunciation to a number of possibilities taken away from the moment of entering a detention institution. The "Pecking order" (Conley, 2004), which explains how in modern society the upper class accumulate more and more benefits causing social damage to lower classes, is certainly indicative of this process of negative causation which multiplies the disadvantages for these people.

A prisoner's life is governed by the imposition of prison governance, which organizes his daily life and establishes its rhythm: each activity corresponds to a specific time and predetermined pattern, prisoners live a life where surprises are rare and every event is largely planned beforehand. All this produces a sense of incapacity, disempowerment and lack of autonomy, well described by the term "infantilisation". From a critical point of view, of great interest is also the concept of "reification", which well explains the prisoner's subjection to the prison system (Pavarini, 2006).

In prisons, life is characterized by a forced cohabitation in few square meters, which determines the alienation of prisoners' lives, far from their affections, loss of sexuality and intimacy; a life full of obligations and rights filtered by constant requests for permission. In prison, all aspects of life are carried out in the same place, under the control of the same prison officer, and all daily activities are organized with precise and determined "fixed rhythms", rationally designed to ensure the governance of what Erving Goffman (Goffman, 1961) defines "total institution": a place of residence and work of groups of people who, left out from society for a considerable period of time, share a common situation, spending most of their lives in a closed and formally administered regime.

To understand the context we are writing about, it seems appropriate to start from the key concepts Goffman exposed in Asylums in 1961. The book opens with a general definition of social institution, which is explained as places, premises, buildings and constructions where certain activities take place with regularity. These institutions occupy part of the time and interests of those who depend on them. In this sense, the Canadian sociologist defines as total institutions those where social exchange and contact with the external world are completely forbidden and impossible, often determined by the physical structure of the institution: locked doors, high walls, barbed wire. Despite the fact that modern man tends to have leisure time, works and sleeps in different contexts, in the total institution all these activities become impossible: First, all aspects of life are performed in the same place and under the supervision of the same single prison officer. Secondly, each phase of daily activities takes place in close connection with a big group of people, all treated in the same way and obliged to do the same things. Thirdly, the different phases of daily activities are strictly carried out one after another according to a predetermined rhythm, as all the activities are imposed by a system of formal explicit rules and by a group of operators. Finally, the various imposed activities are organized according to a single rational plan, designated in order to fulfill the official purpose of the institution. According to the Canadian sociologist, the purpose of the total institution is to erase the individual's personal identity, ruling not one part of his activities but his entire existence, forcing him to become a "genius of survival".

Once inside, the prisoner's relational and personal life is profoundly altered and gradually causes what Donal Clemmer (Clemmer, 1940) defines as the individual's "progressive loss of personality", a condition that the criminologist Cesare Beccaria denounces in Dei Delitti e delle Pene (1764) with the following words: "There is no freedom as long as the laws allow that, in certain conditions, a person ceases being a person and becomes an object."

Donald Clemmer (Ibidem) asserts that crossing the threshold of a total institution involves placing one's identity into the "prisonisation" process. This is a process of progressive depersonalisation, contorting the identity of the person in reclusion and modifying his psychological and emotional saneness. The term "prisonisation" refers to the process the prisoner assumes when undertaking the informal traditions, habits, rules and values characteristic of the society in which he lives (i.e. the prison society). Thus, prisoners are not only deprived of their freedom, but are also subjected to a system of values and needs that are more consistent with the purposes and aims of the institution. This culture makes the prisoner immune to attempts to restore him to society. In other words, the prison serves mainly as a "crime school". According to Clemmer, no prisoner can avoid becoming "prisonised" to some extent: the less contact prisoners have with the external reality, the more close contacts they have with the small groups within the prison. Clemmer thinks that prisonisation has a negative influence on the prisoner, even after his release from prison.

Prisoners often live a state of "ontological insecurity" (Giddens, 1990), that is what Zygmunt Bauman (Bauman, 2000) in a micro sense defines "Unsicherheit", or the complex of experiences defined by the words 
uncertainty, insecurity and unsafety. The spiral triggered by these afflictions is a significant obstacle to collective remedies: people who feel insecure, afraid of what the future might hold for them and fear for their personal safety, seem paralyzed by individual tasks to the point of not being able to imagine different ways of dealing with their problems collectively.

\subsection{Space and Time in Prison}

Management of space and time are a fundamental issue in this context. The Russian writer Andrei Sinyavsky made a remarkable consideration during his father's experience of jail: "Perhaps time is conceived as a space here, this is the enigma. It's like walking through time, but the strangest thing is that instead, you are always at the same place, without moving, your legs are tied and you feel pulled back into the past, so that, returning to you, you are surprised that a year has already passed and it is autumn again” (Sinyavsky, 1987: p. 125). If the space in the cell is in fact "closed", confined and claustrophobic, time is dilated, "open" and perceived as immovable and unchangeable; the only solutions of continuity are made by the rhythms of prison (the alarm, the count, the meals, hours of air, hours of socializing, etc.), which all happen without surprises, marking the inexorable days of detention.

The condition of imprisonment in itself is a source of suffering that goes beyond the simple loss of freedom of movement, particularly for the most vulnerable categories of people. Luigi Berzano (Berzano, 1994) defines "nobody-prisoners" those living at the same time the condition of being a stranger, drug addict and hiv-positive, i.e. people who undergo what I recently called "double burden” (Esposito, 2012). In fact, this condition is due both to the lack of freedom (a common situation for all prisoners) and to health problems (a common situation for sick people). It is a sui generis reality, often accompanied by strong and penetrating sensations and emotions that are hard to manage in that context, where the "biographical disruption" (Bury, 1982) becomes a priority element characterizing the entire existence.

Regarding the Italian situation, the following psychological, relational and health issues were highlighted:

1. erosion of individuality, that is, the damage of the ability to think and act independently,

2. "dis-culturation", that is, the loss of values and attitudes that the person had before entering a prison,

3. physical and psychological damage that affect the individual during the period of his stay in prison,

4. isolation, lack of social interaction with the outside world and with other people locked up in prison,

5. loss of stimulation, adapting to the poverty of the physical environment surrounding the individual and to the monotonous and slow rhythm of institutional life,

6. alienation, that is the inability to adapt to the new environment outside once concluding the experience of prison (Ceraudo, 1988).

To go beyond the total institution, therefore, means to try to regain, even in the detention and reclusive context, the concept of "person", able to combine security and treatment, and therefore able to escape from the always present de-personalizing trap.

\section{International Rules and the Italian Situation between Security and Treatment Paradigms}

\subsection{International Rules on the Rights of Prisoners}

Fundamentally important is the international legislation on the rights of detained persons which is based on the "Universal Declaration of Human Rights" (1948), which states in Article 5 that "No one shall be subjected to torture or to cruel, inhuman or degrading treatment or punishment". This proposition is the cornerstone which affected all future directives concerning the protection of detained people.

As a result, the supranational community attempts to define standards relating to conditions of detention, which the different existing prison systems should conform to. These requirements are gathered by the United Nations (Standard Minimum Rules for the Treatment of Prisoners) in 1955 (henceforth UN), and the Committee of Ministers of the Council of Europe, which approves the European Prison Rules (henceforth EC) in 2006, a set of provisions specifically addressed to the prison world. The purpose of these codes is to establish a set of minimum standards on all the aspects of prison management essential to ensure human conditions of detention and positive treatment.

The first seven articles of the "Basic Principles" of the Rules (EC) assert: 
1. All persons deprived of their liberty shall be treated with respect for their human rights.

2. Persons deprived of their liberty retain all rights that are not lawfully taken away by the decision sentencing them or remanding them in custody.

3. Restrictions placed on persons deprived of their liberty shall be the minimum necessary and proportionate to the legitimate objective for which they are imposed.

4. Prison conditions that infringe prisoners' human rights are not justified by lack of resources.

5. Life in prison shall approximate as closely as possible the positive aspects of life in the community.

6. All detention shall be managed so as to facilitate the reintegration into free society of persons who have been deprived of their liberty.

7. Co-operation with outside social services and as far as possible the involvement of civil society in prison life shall be encouraged.

The key objectives of the rules quoted above can be identified in reaffirming that the purpose of imprisonment is rehabilitation and re-socialization of the prisoner (infra); it must not aggravate the penalty of detention through unreasonable provisions and emphasizes the indispensability of protection and respect of fundamental rights of all individuals and of human dignity. This can be reached through work, educational and vocational training and other activities to be planned within the prison world.

Specifically, this regards work in prisons, which is so specified in EC, at the following articles:

26.1 Prison work shall be approached as a positive element of the prison regime and shall never be used as a punishment.

26.3 As far as possible, the work provided shall be such as to maintain or increase prisoners' ability to earn a living after release.

26.6 Prisoners may choose the type of employment in which they wish to participate, within the limits of what is available, proper vocational selection and the requirements of good order and discipline.

$\mathrm{E}$ in $\mathrm{UN}$, at the following articles:

71. (1) Prison labor must not be of an afflictive nature.

71. (6) Within the limits compatible with proper vocational selection and with the requirements of institutional administration and discipline, the prisoners shall be able to choose the type of work they wish to perform.

72. (1) The organization and methods of work in the institutions shall resemble as closely as possible those of similar work outside institutions, so as to prepare prisoners for the conditions of normal occupational life.

Education and Recreation in prisons are so specified in CE, at the following articles:

27.6 Recreational opportunities, which include sport, games, cultural activities, hobbies and other leisure pursuits, shall be provided and, as far as possible, prisoners shall be allowed to organize them.

28.1 Every prison shall seek to provide all prisoners with access to educational programs which are as comprehensive as possible and which meet their individual needs while taking into account their aspirations.

28.5 Every institution shall have a library for the use of all prisoners, adequately stocked with a wide range of both recreational and educational resources, books and other media.

28.7 As far as practicable, the education of prisoners shall:

a. be integrated with the educational and vocational training system of the country so that after their release they may continue their education and vocational training without difficulty; and

b. take place under the auspices of external educational institutions.

And in UN, at the following articles:

77. (1) Provision shall be made for the further education of all prisoners capable of profiting thereby, including religious instruction in the countries where this is possible. The education of illiterates and young prisoners shall be compulsory and special attention shall be paid to it by the administration.

(2) So far as practicable, the education of prisoners shall be integrated with the educational system of the country so that after their release they may continue their education without difficulty.

78. Recreational and cultural activities shall be provided in all institutions for the benefit of the mental and physical health of prisoners.

In the '70s, perhaps due to the climate of protests, there is a growing interest by politics, the academic world and common people, in issues concerning punishment and its execution, especially in prisons. The "quality leap" towards the statement of the rehabilitation principle dates back to this period. The salient features of the debate of the time are, on one hand, the progressive belief that there should be sanctions other than imprisonment, as in 
the theory on "decarceration" by Scull ${ }^{1}$ (Scull, 1977), and on the other, the strengthening of rehabilitative objectives at the execution stage.

This debate has led to important improvements in the management of the penitentiary institutions at a global level. Two examples ${ }^{2}$ specify these trends. The first is the experimentation of the open cell in Spain: the so called "Módulos de respeto". Opened in the prison Mansilla de las Mulas (León) in 2001 and after a few years adopted by all the Spanish prisons, the so-called Módulo de respeto states that in some sections a particular detention regime has been adopted, providing the open cells throughout the day. Proponents of this model argue that its adoption has led to a significant improvement of the living conditions for many prisoners in terms of increased opportunities for socialization, training, education and, more generally, re-socialization and re-education.

The second example is constituted by the waiting lists and the "open prison" in Norway. Since about twenty-five years, Norway has been applying the so called system of the "waiting lists", devised to avoid overcrowding: entry into prison is subject to the actual possible vacancy. Norway has 46 prisons with a total of 3826 places and there is a very low proportion between inmates and population: 70 prisoners per 100,000 inhabitants, compared with 107 prisoners per 100,000 inhabitants in Italy. The prisons are two types: those with a high security level (closed prisons) and those with a low security level (open prisons). The waiting list does not, however, apply to everybody: there is indeed a selection system based on the risk of re-offending and the type of crime committed, therefore excluding the perpetrators of crimes of violence, sexual exploitation and organized crime.

\subsection{Italian Penitentiary Reform between Security and Treatment Needs}

In Italy, with the penitentiary reform in 1975, the legislator acknowledges and implements Article 27 of the Constitution, the third paragraph reads: "Punishment can not consist in treatment contrary to human dignity and must aim at rehabilitating the offender." The problem of humanization of treatment, associated with the prisoners' social rehabilitation, becomes the central issue and priority of the mission of the penitentiary administration. The prison itself becomes a place where it is necessary to prepare all the social, psychological and structural interventions, able to make the subject assume a new direction for his future life. Regarding the concept of rehabilitation, it can not be identified with interior repentance, moral and spiritual amendment, theoretically possible in any condition. But it is intended as a relational concept, referring to a social life, and implies an active return of the person into the community. To rehabilitate the offender means to reactivate his respect for the fundamental values of social life; re-education must be intended as a synonym for "social rehabilitation" and "re-socialization".

Thanks to the reform of 1975 , there is not the intent of regulating prison administration referring to security and discipline, but the figure of the prisoner as a "person". With this in mind, elements of the prisoner's personality that could help his social rehabilitation have been enhanced. According to the individual prisoner's situation, the treatment which best suits him will be chosen, with a degree of flexibility in the choice, revocation and execution of the method. In the reform context, punishment loses its main value as repression of crimes, and undertakes the "collective responsibility" which leads the individual to violate the criminal law, witnessing the positive obligation that the State has put in act for his reintegration into society.

Article 1 Pen. Code (...) states that "Prisoners and internees are called or referred to by their name (...) For the convicted and internees a rehabilitation treatment must be implemented with the aim of social reintegrating these subjects, through contact with the external environment. The treatment is carried out according to a criterion of individualization in relation to the individuals' specific needs".

In short, it is with the reform of 1975 that changes occur and that the punishment becomes useful for the offender's reintegration, to be achieved through contacts with the outside world. In this regards, it is correct to speak of having a "right" to "prison treatment" (intended as the range of interventions addressing rehabilitation, such as education and work), being characterized by the lack of any type of imposition and always presupposing a voluntary adhesion by the offender. In a practical sense, the exploitation of the rehabilitation principle in the execution of the penalty is achieved through the provision of instruments such as work, education, religious,

\footnotetext{
${ }^{1}$ According to this theory, the aim of social integration of the prisoner no longer requires correctional practices in prison but the direct assumption of deviant in the community and in his social world.

${ }^{2}$ Reported by Associazione Antigone, IX Rapporto nazionale sulle condizioni di detenzione, www.osservatorioantigone.it (accessed 20 November 2012).
} 
cultural, recreational and sports activities, as well as contacts with the outside world and family relations. Thus, treatment measures consist of many different types of activities, all connected together by the fact of being included in the individualized treatment program.

This brief mention of what the rehabilitation treatment should consist of is sufficient to give rise to critical questions about its effective implementation.

The situation in Italy is in fact very far from the effective realization of these principles. The results of the recent report on the state of the prisons in Italy by the association "Antigone" (Antigone, 2012) attests to a very problematic reality: Italy is one of the countries with the most overcrowded prisons in the European Union: our rate of overcrowding is of $142.5 \%$ (over 140 prisoners per 100 places) while the European average is 99.6\%. In October 2012, in fact the overall regulatory capacity of the 206 Italian prisons was 46,795 places, compared to the presence of 66,685 prisoners. There are prisons in which four prisoners are crowded into nine square meters, others where they are locked up to 20 hours a day, or where in winter the heaters are off. Besides, less than a quarter of the inmates in prison is engaged in school activities. In October 2012, the shortage of educators was $27.2 \%$, that of social workers was as high as $35.1 \%$, while the lack of officers dropped to only $8 \%$. According to statistics from the Council of Europe (Aebi \& Delgrande, 2011), Italy is the European country with the lowest ratio between educational/psychological staff and custodial staff.

The main limitations of the legal guidelines derive from structural factors, that is, the fact that rehabilitation is carried out in a closed institution, but also from other factors, of a contingent nature, such as the overcrowding of prisons, lack of suitable infrastructures for social and psychological research and the serious problem regarding the often conflicting relationship between the rehabilitation experts (psychologists, psychotherapists, educators, social workers) and the prison officers. The latter tend to consider the former as enemies or intruders disturbing the normal equilibrium of prisons (these criticisms were already highlighted in Italy four years after the penitentiary reform by Dolcini, 1979). At the international level, this problem is often confirmed: prisoners live a state of emptiness, affective instability, loss of sense, of "expropriation" of their own health (Illich, 1976) and it is in this dimension of disorientation of the Self that words and dialogue must find space. But all this is put to the test in prison life: as stated by Diana Medlicott (Medlicott, 2001: p. 221), the ability to engage a truly empathic relationship with the inmate is actually put to the test by the evident machismo that is breathed in prisons, so that to undertake a relationship of active listening, sharing feelings and empathic attention by prison officers or other professionals who work within the structure can easily generate confusion and misunderstanding on the type of relationship wanted.

\section{Concluding Remarks on the Importance of Prisoners' Rehabilitation Treatments}

The introduction of the humanization concept, requirements to ensure respect for the dignity of the person, the recommendation to eliminate any form of depersonalization, the necessity of promoting contacts with the external environment are essential cornerstones on which the new organization of prisons in Italy have been planned. A necessary clarification allows us to recall that the already mentioned Standard Minimum Rules for the Treatment of Prisoners UN assert, at the following articles:

61. The treatment of prisoners should emphasize not their exclusion from the community, but their continuing part in it. Community agencies should, therefore, be enlisted wherever possible to assist the staff of the institution in the task of social rehabilitation of the prisoners. There should be in connection with every institution social workers charged with the duty of maintaining and improving all desirable relations of a prisoner with his family and with valuable social agencies. Steps should be taken to safeguard, to the maximum extent compatible with the law and the sentence, the rights relating to civil interests, social security rights and other social benefits of prisoners.

65. The treatment of persons sentenced to imprisonment or a similar measure shall have as its purpose, so far as the length of the sentence permits, to establish in them the will to lead law-abiding and self-supporting lives after their release and to fit them to do so. The treatment shall be such as will encourage their self-respect and develop their sense of responsibility.

66. (1) To these ends, all appropriate means shall be used, including religious care in the countries where this is possible, education, vocational guidance and training, social casework, employment counseling, physical development and strengthening of moral character, in accordance with the individual needs of each prisoner, taking account of his social and criminal history, his physical and mental capacities and aptitudes, his personal 
temperament, the length of his sentence and his prospects after release.

These principles do not only have purely ethical or solidarity implications, linked to not having to neglect and forget anyone and to take care of people beyond their specific personal stories, but have, above all, a social aspect, related to the return into society of these individuals, and hence a broader issue of social security and quality of life for all. This is validated empirically in a study conducted in 2011 by the University of Missouri ${ }^{3}$, that found that educating inmates and preparing them to find jobs upon their release from prison greatly reduces the recidivism rate. Inmates who take advantage of the educational opportunities available to them in prison are more likely to find a job than those who do not.

The complex educational activities, if carried out in the closed penitentiary institution, become artificial and unnatural and based on models of unreal relationships, where the social environment is missing; therefore, it is necessary to give importance to the choice of getting involved in an experience that may vary in its content aspects (education, work, recreation, sports and cultural activities) but must be characterized by the "formative" dimension which invests the person completely and becomes a moment of "fracture" (the meaning Michael Bury gives-as seen supra-the concept of "biographical disruption"), with respect to the experience of life known until then.

Therefore, speaking of rehabilitative model means to restore solidarity with the socially recognized values, reconstructing the broken citizenship bond. The objective of rehabilitation cannot, in fact, leave out of consideration the individual's acquisition of the awareness of the unlawful conduct carried out and the consequences the offense has produced, preliminary moment of change and transformation.

Assuming that prison is a necessary evil (and therefore should be used sparingly by the legislator), we believe that the "collateral damage" caused by detention, especially for long-term periods, should be limited as much as possible. Treatment activities, in this context, should be understood as instruments to counteract the damage of "prisonisation" capable of increasing the prisoner's chances of social rehabilitation. To counter the negative effects of imprisonment we hope, above all, for the progressive opening of prisons towards the external society through a greater collaboration with the institutions and socio-cultural and economic extra-structure realities, and through the adoption of methods of conducting the internal life in prisons inspired by European Rules models which actively involve the inmate.

He must not be "reinserted" passively, but helped to regain his ability to use relational resources of his social network outside the walls (social empowerment). Nowadays, therefore, the prison treatment should not consist of a program to change the behavior of the prisoner for after his release, but in providing opportunities for social reintegration that are part of a life plan not necessarily determined by the operator. Self-management of certain activities within the structure (cleaning and maintenance of cells, organization of sports and cultural activities, etc.) can be considered, in this context, functional to avoid depersonalization processes and relational apathy that often occur after long periods of detention.

In this view, all the activities that usually make up the complex educational activities (work and education, artistic/expression activities, cultural/recreational and sport activities) should be implemented from the perspective of learning directed towards a goal of promoting personal and cultural life (family, work, social context). Fundamentally, it is to create a "formative space" within the prison that also becomes a place for socializing and relationships, characterized by the pleasure of meeting others and freedom of expression, in order to promote the development of a critical awareness of one's life and the planning of one's future life.

Each treatment activity, must, to the extent possible, become a moment of critical reflection, assumption of responsibility, maturity, willingness to take on a socially acceptable behavior, abandoning that abstract and not significant acceptance associated with activities aimed at purely entertaining the prisoner, to ensure him a better quality of life during his stay in prison.

Only by putting the formative approach at the center of the activity model, using innovative criteria for learning and building a strong system of needs analysis, will it be possible to implement a real contrast to social exclusion and poverty, facilitating the re-integration of those who are on the margins of social life and the labour market.

In conclusion, empowering prisoners is a fundamental issue because their problems are problems of the whole society. In order to represent a real expression of change, innovation and successful rehabilitation, the prison

\footnotetext{
${ }^{3}$ Jake Cronin, a policy analyst with the Institute of Public Policy in the Truman School of Public Affairs at the University of Missouri, on http://www.sciencedaily.com/releases/2011/10/111004180121.htm (accessed 23 November 2012).
} 
must be transformed from a "total" institution to a "social" institution, and able to provide a constructive sense to those suffering imprisonment. Paradoxically, in agreement with important international studies (Marquart \& Merianos, 1996), prisons will have to be considered not only in the "endogenous" sense, as a place where it is possible to promote and maintain prisoner quality of life, but also and especially as an opportunity to improve the quality of the environment from which the prisoner originates. Therefore, prisons could become the place where prevention strategies offer the prisoner, once released, the opportunity of reintegrating into the community without problems that are more severe than those he had before entering prison.

\section{References}

Aebi, M., \& Delgrande, N. (2011). Council of Europe. Annual Penal Statistics 2009. Lausanne: Université de Lausanne.

Antigone Associazione (2012). IX Rapporto nazionale sulle condizioni di detenzione. www.osservatorioantigone.it

Bauman, Z. (2000). La solitudine del cittadino globale. Milano: Feltrinelli.

Berzano, L. (1994). La pena del non lavoro. Milano: Franco Angeli.

Bury, M. R. (1982). Chronic Illness as Biographical Disruption. Sociology of Health and Illness, 4, 2. http://dx.doi.org/10.1111/1467-9566.ep11339939

Ceraudo, F. (1988). Principi fondamentali di medicina penitenziaria. Pisa: Centro Studi Amapi.

Clemmer, D. (1940). The Prison Community. New York: Holt, Rinehart \& Winston.

Conley, D. (2004). The Pecking Order. New York: Pantheon.

Dolcini, E. (1979). La rieducazione del condannato fra mito e realtà. Rivista italiana diritto procedura penale. 469.

Esposito, M. (2012). Double Burden: A Qualitative Study of Unhealthy Prisoners in Italy. International Journal of Prisoner Health, 8, 35-44. http://dx.doi.org/10.1108/17449201211268273

Giddens, A. (1990). The Consequences of Modernity. Oxford: Polity Press.

Goffman, E. (1961). Asylums: Essays on the Social Situation of Mental Patients and Other Inmates. New York: Anchor Books, Doubleday \& Company.

Illich, I. (1976). Medical Nemesis. The Expropriation of Health. London: Calder \& Boyars.

Marquart, J. W., \& Merianos, D. W. (1996). Thinking about the Relationship between Health in the Free Community and the Prison. Crime \& Delinquency, 42, 331-360. http://dx.doi.org/10.1177/0011128796042003001

Medlicott, D. (2001). Surviving the Prison Place. Surrey: Ashgate.

Pavarini, M. (2006). La lotta per I diritti dei detenuti tra riduzionismo e abolizionismo carcerari. Antigone, anno I n.1.

Scull, A. T. (1977). Decarceration. Community Treatment and the Deviant: A Radical View. Upper Saddle River, New Jersey: Prentice-Hall.

Sinyavsky, A. (1987). Buona notte. Milano: Garzanti.

Vianello, F. (2012). Il carcere. Sociologia del penitenziario. Roma: Carocci. 